\title{
KESEPIAN PADA MIDDLE AGE YANG MELAJANG (Studi Fenomenologis Tentang Tipe Kesepian)
}

\author{
LONELINESS ON SINGLE MIDDLE AGES
}

(Study of Phenomenology on type of Loneliness)

\author{
Oleh : \\ Diah Putri Wardani*) \\ Dyah Siti Septiningsih**)
}

\begin{abstract}
ABSTRAK
Penelitian ini bertujuan untuk mengkaji tipe kesepian pada middle age yang masih melajang di Purwokerto.Penelitian ini menggunakan metode penelitian kualitatif dengan pendekatan fenomenologis. Hasil penelitian menunjukkan bahwa informan 1 berjenis kelamin pria menunjukkan 7 tipe kesepian yang dialami yaitu kesepian emosional (sedang melakukan tahap pendekatan dengan lawan jenis), mengalami interpersonal loneliness (merindukan wanita yang pernah dekat, setelah putus dengan wanita tersebut banyak menjalin hubungan dengan lawan jenis), kesepian kosmik (belum memiliki wanita yang cocok untuk dinikahi, memiliki pemikiran bahwa menjalin hubungan dengan wanita yang berjarak jauh tidak akan berjalan lancar), kesepian kognitif (jarang mencurahkan hati dengan orang lain), kesepian psikologikal (pengalaman masa lalu berpengaruh untuk kehidupan saat ini sehingga merasa kecewa, menyesal, merasa bersalah dan merasa kena kualat), kesepian perilaku (berbagai kegiatan dilakukan sendiri), dan kesepian sosial (tidak memiliki peran dalam masyarakat). Informan 2 berjenis kelamin pria menunjukkan 4 tipe kesepian yang dialami yaitu kesepian emosional (ingin memiliki hubungan yang serius dengan lawan jenis), kesepian kosmik (belum memilki wanita yang cocok untuk dinikahi, merasa tidak mungkin menjalin hubungan dengan wanita karena merasa belum mapan dari segi ekonomi), kesepian kognitif (jarang mencurahkan hati dengan orang lain, lebih memilih Allah SWT sebagai tempat curahan hatinya) dan kesepian perilaku (berbagai kegiatan dilakukan sendiri). Informan 3 berjenis kelamin wanitamenunjukkan 4 tipe kesepian yang dialami yaitu kesepian emosional (merasa kurang mendapatkan kasih sayang dari keluarga dan belum terpenuhi), kesepian kognitif (hanya mencurahkan hati dengan kakak), kesepian sosial (tidak memiliki peran dalam masyarakat, keadaan lingkungan tempat tinggal sepi), dan culture shock (merasa kesulitan menyesuaikan diri saat berada dilingkungan baru).
\end{abstract}

Kata Kunci : Tipe Kesepian, Middle Age, Lajang.

*) Alumni Fakultas Psikologi Universitas Muhammadiyah Purwokerto

**) Dosen Fakultas Psikologi Universitas Muhammadiyah Purwokerto 


\begin{abstract}
This research aimed to analyzed the type of loneliness on single middle ages person in Purwokerto. This research used qualitative method by phenomenological approach. Research result showed that informant 1, male, experienced 7 kinds of loneliness; emotional loneliness (in an approaching stage to the opposite sex), experiencing interpersonal loneliness (missing ex-girl and made relationship with many others as aftereffect), cosmic loneliness (does not have right woman to be married for, thought that having long distance relationship would not work well), cognitive loneliness (rarely confide to others), psychological loneliness (past experience affected present life with regrets, disappointment, guilt, and damnation), behavioral loneliness (lone wolf), and social loneliness (did not have role in society). Informant 2, male, experienced 4 kinds of loneliness; emotional loneliness (strong urge to have serious relationship), \cosmic loneliness (does not have right woman to be married for, afraid to make relationship due to unsettled economic condition), cognitive loneliness (rarely confide to others, and preferred to confess to God), and behavioral loneliness(lone wolf). Informant 3, female, experienced 4 kinds of loneliness; emotional loneliness (lack of affection from family that has not been fulfilled), cognitive loneliness (only confide to her sister), social loneliness (did not have role in society) and experiencing culture shock (difficult to adapt to new environment).
\end{abstract}

Keyword : Type Of Loneliness, Middle Age, Single

\title{
PENDAHULUAN
}

Manusia sejatinya adalah makhluk sosial yang dimana tidak akan pernah lepas hubungan dengan orang lain serta membutuhkan hubungan interpersonal dengan orang lain contohnya ketika memasuki usia dewasa, hubungan interpersonal dengan orang lain bisa lebih mendalam sampai ke tahap pernikahan yang dimana seseorang tersebut memiliki pasangan dalam hidupnya. Pernikahanmerupakan suatu bentuk tahap perkembangan ketika seseorang mulai memasuki usia dewasa.

Hurlock (1980) mengatakan bahwa pada masa dewasa awal memiliki tugas yang dipusatkan pada harapan-harapan masyarakat seperti mendapatkan pekerjaan, memilih seorang teman hidup, belajar hidup dengan suami atau istri membentuk suatu keluarga, membesarkan anak-anak, mengelola sebuah rumah tangga, menerima tanggung jawab sebagai warga negara dan kelompok sosial.

Namun, tidak semua orang yang sudah memasuki usia dewasa menikah, karena memang ada individu-individu yang sebenarnya sudah memasuki usia dewasa bahkan sudah sampai memasuki middle age (masa dewasa pertengahan) belum memutuskan untuk menikah.Hal ini terlihat dari data-data sensus penduduk maupun penelitian yang menurut sumber data statsistik Indonesia tahun 2008, mengenai penduduk yang berusia 15-49 tahun yang membujang atau sekarang 
yang dikenal dengan istilah lajang yang jumlahnya mencapai sekitar $1,71 \%$ pada tahun 2000 (dalam Oktaria, 2009).

Sementara salah satu tugas tugas perkembangan middle age (masa dewasa pertengahan) meliputi hal-hal yang berkaitan dengan kehidupan keluarga seperti sebagai pasangan suami-istri, menyesuaikan diri dengan orang tua yang lanjut usia, dan membantu anak remaja untuk menjadi orang dewasa yang bertanggung jawab dan bahagia (Hurlock, 1980).

Sumanto (2014) menyatakan bahwa dalam setiap budaya ada tugas perkembangan (developmental task), yaitu tugas-tugas atau keterampilanketerampilan atau pola perilaku tertentu yang harus dipenuhi oleh individu dalam suatu masa kehidupan tertentu. Individu yang dapat memenuhi tugas perkembangan akan bahagia dan menjadi dasar bagi keberhasilan tugas-tugas selanjutnya.Sebaliknya individu yang gagal dalam memenuhi tugas perkembangannya tidak akan bahagia dan sulit untuk memenuhi tugas perkembangan pada masa selanjutnya. Misalnya ada beberapa pria dan wanita yang sudah memasuki middle age (masa dewasa pertengahan) belum pernah menikah atau belum memiliki pasangan hidup, hal ini akan menyulitkannya untuk memperoleh atau membentuk sebuah keluarga dan mendapatkan keturunan saat masa tua.Karena pada masa ini, wanita mulai mengalami menopause (berhentinya menstruasi setelah indung telur berhenti memproduksi estrogen dan progesteron) sehingga potensi untuk mengandung atau melahirkan anak tak memungkinkan lagi (Sumanto, 2014). Sedangkan menurut Wyrobek, dkk (dalam Wade, 2008) mengatakan bahwa pria pada masa ini secara teori tetap subur seumur hidup, namun pria juga memiliki jam biologis. Pria mengalami penurunan pada testosteron namun tidak drastis seperti estrogen pada wanita.Jumlah sperma memang secara bertahap menurun, dan sperma yang tetap ada lebih rentan terhadap mutasi genetik sehingga dapat meningkatkan resiko munculnya penyakit-penyakit tertentu pada anak yang lahir dari ayah yang berusia lebih lanjut.

Feldman (dalam Desmita, 2009) mengatakan pada umumnya Psikolog menetapkan sekitar usia 20 tahun sebagai masa dewasa dan berlangsung sampai sekitar usia 40-45 tahun, pertengahan masa dewasa berlangsung dari sekitar usia 40-45 tahun sampai sekitar usia 65 tahun serta masa dewasa lanjut atau masa tua berlangsung dari sekitar usia 65 tahun sampai meninggal.

Beck (dalam Santrock, 1995) usia tengah baya atau masa dewasa tengah adalah antara usia 40 tahun hingga kira-kira 60 sampai 65 tahun dan dengan semakin banyaknya orang yang hidup lebih panjang, batas atas 60 hingga 65 tahun mungkin akan terdorong ke atas.

Masa dewasa pertengahan (middle age) merupakan bagian rentang kehidupan yang paling sedikit dipelajari. Tahun-tahun pertengahan dianggap sebagai ruang kosong menjemukan di antara perubahan yang lebih dramatis masa dewasa awal dan usia tua. Masa dewasa pertengahan (middle age) dalam 
terminologi kronologis, yaitu tahun-tahun antara usia 45 tahun sampai 65 tahun (Papalia, Sally \& Ruth, 2008).

Menurut Sumanto (2014) masa dewasa madya merupakan masa yang penuh dengan tantangan, karena kondisi fisik mulai mengalami kemerosotan yaitu mulai menipisnya rambut kepala, kerusakan pada gigi, menurunnya sensitivitas pendengaran, penglihatan, dan lain-lain.Dalam kehidupan karier, masa dewasa madya merupakan masa puncak untuk prestasi dan mendapatkan posisi-posisi penting di lembaga-lembaga perusahaan, pendidikan dan pemerintahan.Dengan demikian individu pada masa dewasa madya telah mapan kehidupan ekonomi keluarganya. Dalam kehidupan yang telah mapan, kelebihan berat badan adalah masalah kesehatan yang serius bagi orang yang memasuki dewasa madya. Pada usia tersebut di Amerika Serikat (USA) dimana 30\% atau lebih mengalami kelebihan berat badan yang mengakibatkan probabilitas risiko kematian meningkat $40 \%$. Kelebihan berat badan juga memicu munculnya penyakitpenyakit ringan, darah tinggi, dan penyakit pencernaan.

Menurut Wethington (dalam Wade, 2008), usia paruh baya merupakan masapuncakdimana kondisi kesejahteraan psikologis, kesehatan, produktivitas, dan keterlibatan dalam masyarakat sangat optimal. Masa-masa ini juga seringkali merupakan waktu untuk melakukan refleksi dan peninjauan kembali. Orang melihat kembali hal-hal yang telah dicapai, merinci hal-hal yang disesali atau yang tidak pernah dilakukan, dan berpikir tentang apa yang hendak dilakukan dengan sisa hidup yang dimiliki. Saat krisis terjadi, hal ini dikarenakan ada alasan yang tidak berhubungan dengan bertambahnya usia, melainkan karena kejadiankejadian spesifik yang mengubah hidup seseorang, misalnya terjangkit penyakit atau kehilangan pekerjaan atau pasangan.

Berbagai pendapat dari tokoh diatas mengenai penamaan masa dewasa pertengahan yang berbeda-beda seperti dewasa menengah, masa dewasa madya, usia tengah baya, dewasa madya, usia paruh baya, namun pengertian dari berbagai tokoh mengandung makna yang sama hanya pembagian usia masing-masing tokoh memiliki perbedaan pendapat dan dari perbedaan penamaan serta pembagian usia diatas. Dalam penelitian ini peneliti hanya akan menggunakan satu nama yaitu middle age(masa dewasa pertengahan)sesuai dengan pendapat Papalia, Sally \& Ruth (2008) yang dimana individu yang memasuki masa dewasa pertengahan (middle age) adalah individu berusia 45 tahun sampai usia 65 tahun dengan mengalami perubahan yang terjadi mulai dari kemerosotan kondisi fisik, pada wanita mulai mengalami menopause, sedangkan pria mengalami penurunan pada testosterone, selain itu pada masa ini merupakan masa puncak untuk meraih prestasi.

Menurut Hurlock (1980), salah satu ciri pada tahap perkembanganmiddle age (masa dewasa pertengahan)ini merupakan masa sepi (empty nest). Dalam beberapa kasus dimana pria dan wanita menikah lebih lambat dibandingkan dengan usia rata-rata, atau menunda kelahiran anak hingga mereka lebih mapan dalam karier, atau mempunyai keluarga besar sepanjang masa, dewasa madya merupakan masa sepi dalam kehidupan perkawinan. 
De Jong-Giervield (dalam Santrock, 1995) menyatakan pendapatnya bahwa sebagian dari manusia adalah individu yang kesepian. Setiap manusia mungkin merasa bahwa tidak seorang pun memahaminya dengan baik.Seseorang mungkin merasa terisolasi dan merasa bahwa tidak memiliki seorang pun untuk dijadikan pelarian saat dibutuhkan atau saat stres. Penekanan masyarakat pada pemenuhan diri dan prestasi, pentingnya komitmen dalam suatu hubungan, dan penurunan dalam hubungan dekat adalah sebagian alasan adanya perasaan kesepian yang umum terjadi sekarang.

Suardiman (2011) menyatakan bahwa kesepian akan sangat dirasakan oleh individu yang hidup sendirian, tanpa anak, kondisi kesehatannya rendah, tingkat pendidikannya rendah, introvert, rasa percaya diri rendah, kondisi sosial ekonomi rendah sebagai akibat pensiun menimbulkan perasaan kehilangan prestise, hubungan sosial, kewibawaan dan sebagainya.

Berdasarkan uraian diatas, dapat disimpulkan bahwa ketika individu sudah mencapai middle age (masa dewasa pertengahan)selain mengalami banyak perubahan dalam hidupnya seperti kemerosotan kondisi fisik, pada wanita mulai mengalami menopause, sedangkan pria mengalami penurunan pada testosteron, pada masa ini merupakan masa puncak untuk meraih prestasi selain itu juga mengalami permasalahan psikologis yaitu kesepian yang dialami olehmiddle age (masa dewasa pertengahan) yang melajang (belum menikah / belum memiliki pasangan hidup). Hal ini terjadi karena menurut Hurlock (1980) salah satu ciri perkembanganmiddle age (masa dewasa pertengahan) adalah masa sepi (empty nest) yang dimana dalam beberapa kasus antara pria dan wanita menikah lebih lambat dibandingkan dengan usia rata-rata. Oleh karena itu, peneliti tertarik untuk meneliti mengenai kesepian yang dialami oleh middle age (masa dewasa pertengahan) yang masih melajang.

\section{METODE PENELITIAN}

\section{A. Pendekatan Penelitian}

Penelitian kualitatif ini menggunakan metode pendekatan fenomenologis yang berusaha untuk memahami suatu peristiwa yang berkaitan dengan orang-orang yang berada dalam situasi tersebut.Pendekatan fenomenologis ini bertujuan untuk dapat memberikan tipe kesepian pada middle age (masa dewasa pertengahan) khususnya yang masih melajang (belum pernah menikah / belum memiliki pasangan hidup).

\section{B. Fokus Penelitian}

Pada penelitian ini, peneliti terfokus pada tipe kesepian yang dialami oleh informan yang memasuki middle age (masa dewasa pertengahan) yang masih melajang (belum pernah menikah / belum memiliki pasangan hidup).

\section{Informan Penelitian}


Pada penelitian ini, informan yang digunakan adalah informan primer dan informan sekunder, serta bersifat terbatas atau hanya informan yang sesuai dengan kriteria tertentu saja yang sesuai dengan tujuan penelitian ini.

Kriteria informan tersebut adalah sebagai berikut :

1. Informan primer :

a. Middle age (masa dewasa pertengahan) yang melajang (belum pernah menikah / belum memiliki pasangan hidup).

b. Batasan usia yang digunakan dalam penelitian ini mengacu pada batasan usia yang dikemukakan oleh Papalia, Shally \& Ruth (2008) bahwa middle age (masa dewasa pertengahan) terjadi diantara usia 45 tahun sampai 65 tahun.

2. Informan sekunder, yaitu orang yang mengenal informan primer dengan baik dan tahu tentang informan primer seperti saudara.

\section{Metode dan Alat Pengumpulan Data}

Dalam penelitian ini, pengumpulan data akan dilakukan pada natural setting (kondisi yang alamiah) dan metode yang akan digunakan dalam mengumpulkan data antara lain :

\section{Observasi}

Jenis observasi yang akan digunakan oleh peneliti dalam penelitian ini adalah menggunakan observasi terus terang atau tersamar.

2. Wawancara

Jenis wawancara yang digunakan dalam penelitian ini adalah menggunakan wawancara semi standar (semistandardized interview).Wawancara ini untuk mengungkap tipe kesepian yang dialami oleh middle age (masa dewasa pertengahan) yang masih melajang.

3. Alat Pengumpul Data

a. Pedoman ini digunakan untuk melihat perilaku yang muncul dalam diri informan. Hasil observasi ini digunakan sebagai catatan lapangan yang bersifat deskriptif.

b. Pedoman interview (wawancara)berisi butir-butir pertanyaan mengenai kesepian dantipe-tipe kesepian, sehingga pertanyaan yang diajukan menjadi terarah.

c. Rekaman (tape recorder), berfungsi untuk merekam semua percakapan atau pembicaraan.

d. Buku catatan, berfungsi untuk mencatat semua percakapan dan perilaku subyek penelitian.

\section{E. Kredibilitas}

Dalam penelitian ini, peneliti menggunakan triangulasi. Dengan menggunakan triangulasi dalam pengujian kredibilitas ini, peneliti dapat melakukan pengecekan data dari berbagai sumber dengan berbagai cara, dan berbagai waktu.

\section{F. Analisis Data}

Analisis data dalam penelitian ini menggunakan model interaktif (interactive model of analysis) dimana komponen-komponen analisis data secara interaktif saling berhubungan selama dan sesudah pengumpulan data. 


\section{HASIL DAN PEMBAHASAN}

Dari ketiga informan primer memiliki profil pekerjaan yang berbeda dengan tingkat pendidikan yang sama. Lebih jelasnya profil tentang informan primer dapat dilihat pada tabel berikut :

Tabel 1. Profil Informan Primer

\begin{tabular}{ccccc}
\hline Informan & Usia & Jenis Kelamin & Pendidikan & Pekerjaan \\
\hline EH & $53 \mathrm{Th}$ & Pria & SMA & Pedagang \\
\hline DI & $49 \mathrm{Th}$ & Pria & SMA & Tukang Parkir \\
\hline KI & $50 \mathrm{Th}$ & Wanita & SMA & Tidak Bekerja \\
\hline
\end{tabular}

Tabel 2. Profil Informan Sekunder

\begin{tabular}{ccccc}
\hline Informan & Usia & Pendidikan & Pekerjaan & $\begin{array}{c}\text { Hubungan dengan } \\
\text { Informan Primer }\end{array}$ \\
\hline WI & $33 \mathrm{Th}$ & Sarjana & Aid Teacher & $\begin{array}{c}\text { Keponakan Informan } \\
\text { EH dan DI }\end{array}$ \\
\hline AM & $29 \mathrm{Th}$ & Sarjana & Karyawan Swasta & $\begin{array}{c}\text { Keponakan Informan } \\
\text { KI }\end{array}$ \\
\hline
\end{tabular}

Tabel 3. Temuan Tipe Kesepian yang dialami Informan

\begin{tabular}{|c|c|c|c|c|c|c|c|c|c|c|}
\hline$\stackrel{\circ}{Z}$ & 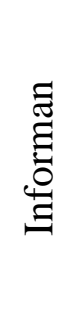 & 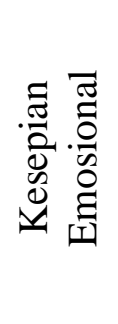 & 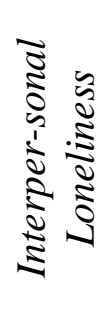 & 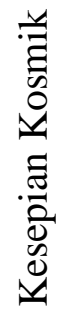 & 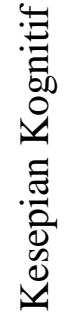 & 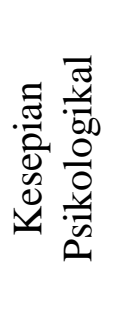 & 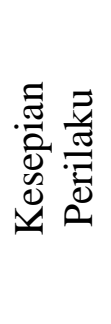 & 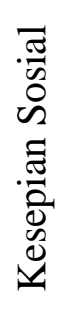 & 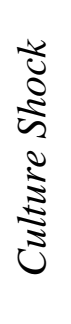 & \\
\hline 1. & $\mathrm{EH}$ & $\checkmark$ & $\checkmark$ & $\checkmark$ & $\checkmark$ & $\checkmark$ & $\checkmark$ & $\checkmark$ & - & 7 \\
\hline 2. & DI & $\checkmark$ & - & $\checkmark$ & $\checkmark$ & - & $\checkmark$ & - & - & 4 \\
\hline 3. & $\mathrm{KI}$ & $\checkmark$ & - & - & $\checkmark$ & - & - & $\checkmark$ & $\checkmark$ & 4 \\
\hline
\end{tabular}

Pada informan EH ditemukan keterangan bahwa informan sedang melakukan tahap pendekatan dengan lawan jenis. Pada informan DI ditemukan keterangan bahwa belum memiliki seseorang (wanita) yang dekat dalam hidupkarena belum menemukan yang cocok.Informan DI ingin memiliki hubungan yang serius jika memiliki seseorang (wanita)yang dekat dengannya. 
Berdasarkan paparan pernyataan dari informan EH dan informan DI diatas, sesuai dengan pendapat Bruno (2000) yang mengatakan bahwa kesepian emosional terjadi bila individu membutuhkan kasih sayang namun tidak mendapatkannya. Dari pendapat ini, informan EH dan informan DI mengalami kesepian emosional, meskipun informan EH sedang melakukan tahap pendekatan dengan lawan jenis, hal ini menunjukkanbahwa informan EHmembutuhkan kasih sayang.Informan DI belum memiliki hubungan dekat dengan lawan jenis dan ingin memiliki hubungan yang serius dengan lawan jenis.Kedua informan diatas telah menunjukkan bahwa antara informan $\mathrm{EH}$ dan informan DI membutuhkan kasih sayang namun tidak mendapatkannya.

Sedangkan informan KI mengungkapkan bahwa tidak memiliki seseorang (pria) yang dekat dengan dirinya. Informan KI juga mengatakan bahwa kasih sayang dari keluarga kurang dan belum terpenuhi.Hal ini sesuai dengan pendapat Robert Weiss (dalam Sears, Jonathan \& Peplau, 1988) yang mengatakan bahwa kesepian emosional timbul dari ketiadaan figur kasih sayang yang intim, seperti yang biasa diberikan orang tua kepada anaknya atau yang bisa diberikan tunangan atau teman akrab kepada seseorang. Dengan demikian informan KI juga mengalami kesepian emosional seperti informan EH, dan informan DI.

Sadler (dalam Oktaria, 2009), interpersonal lonelines terjadi manakala individu merindukan seseorang yang dahulu pernah dekat dengannya dan melibatkan kesedihan yang mendalam sehingga individu mencari-cari orang baru untuk dicintai. Namun jika menemukan orang yang potensial menjadi pasangan baru sebelum ia mampu mengatasi kesedihan terdahulu, maka individu akan takut dan menolak.

Berdasarkan pernyataan yang dikemukaan oleh Sadler (dalam Oktaria, 2009) diatas sesuai dengan hasil penemuan penelitian pada informan EH.Informan EH menyatakan pernah merindukan sosok wanita yang pernah dekat dengannya.Namun setelah memutuskan hubungan dengan wanita tersebut,informan EH banyak menjalin hubungan dekat dengan lawan jenis lain. Informan EH juga mengatakan bahwa semasa mudanya, banyak memiliki pacar serta banyak teman kerja yang menyukainya.Dengan demikian, ditemukan bahwa informan EH mengalami interpersonal loneliness seperti yang diungkapkan oleh Sadler (dalam Oktaria, 2009).

Berbeda dengan informan DI dan informan KI yang dimana kedua informan ini tidak ditemukan mengalami interpersonal loneliness seperti yang dikatakan Sadler (dalam Oktaria, 2009).Karena kedua informan ini mengatakan tidak memiliki perasaan rindu terhadap lawan jenis yang pernah dekat.Selain itu, kedua informan ini juga tidak mencari-cari sosok yang baru untuk dicintai.

Dari hasil penelitian yang telah dilakukan, ditemukan bahwa pada informan EH dan informan DI sama-sama pernah menjalin hubungan dengan lawan jenis. Namun, hanya sampai pada tahap pacaran atau tidak sampai pada tahap pernikahan. Selain itu, ditemukan juga bahwa kedua informan mengalami kesepian kosmik. Karena kedua informan sama-sama merasa belum memiliki 
seseorang (wanita) yang cocok untuk dinikahi dan merasa belum berjodoh. Kedua informan memiliki perasaan ketidakmungkinan untuk menjalin hubungan yang sempurna dengan orang lain. Hal ini ditemukan saat informan EH mengatakan bahwa saat menjalin hubungan dengan lawan jenis dengan jarak jauh itu tidak akan berjalan lancar. Sedangkan informan DI jika kelak menjalin hubungan dengan lawan jenis, informan DI menginginkan lawan jenisnya mau menerima keadaannya yang sering keluar kota untuk kegiatan dikomunitas sepeda ontel. Karena informan DI merasa bahwa dunianya berada disepeda ontel.Informan DI jugamemiliki pemikiran bahwa kebanyakan orang mengejar masalah dunia, meskipun sebenarnya manusia perlu dunia namun untuk meraih itu juga perlu dilihat dari segi kemampuan sehingga DI merasa tidak mungkin untuk menjalin hubungan dengan lawan jenis karena belum mapan dalam ekonomi.

Informan EH dan informan DI sama-sama memiliki keinginan untuk menikah dan memiliki keluarga.Namun karena kedua informan ini memilikiperasaan ketidakmungkinan seperti yang telah dipaparkan diatas, sehingga pada akhirnya perasaannya lah yang menjadi penghalang untuk menjalin hubungan dengan lawan jenis sampai pada tahap pernikahan. Hal ini sependapat dengan Sadler (dalam Oktaria, 2009) yang mengatakan bahwa kesepian kosmikdikenal dengan kesepian eksistensial yang perasaanketidakmungkinan untuk menjalin suatu hubungan yang sempurna dengan orang lain. Sedangkan pada informan KI tidak ditemukan mengalami kesepian kosmik seperti yang dikemukakan oleh Sadler (dalam Oktaria, 2012). Karena informan KI mengatakan bahwa merasa biasa saja ketika menjalin hubungan dengan lawan jenis.Informan $\mathrm{KI}$ hanya ingin bersenang-senang dengan orang-orang yang berada disekitarnya.

Menurut Bruno (2000), kesepian kognitif terjadi jika individu mempunyai sedikit teman untuk berbagi pikiran atau gagasan yang dianggap penting. Berdasarkan pendapat Bruno (2000), ditemukan bahwa ketiga informan yaitu EH, DI, dan KI mengalami kesepian kognitif.

Informan EH dan informan DI mengatakan jarang mencurahkan hati dengan teman-teman namun lebih sering menjadi tempat curahan hati temanteman. Selain itu, informan EH, DI, dan KI mengalami kesulitan dalam bertukar pikiran dengan orang lain. Informan $\mathrm{EH}$ mengaku memiliki teman untuk bertukar pikiran atau mencurahkan hati namun itu hanya sebatas hal-hal yang bersifat umum sedangkan untuk hal yang bersifat pribadi, informan EH tidak menceritakannya.Informan DI lebih memilih Allah SWT.untuk dijadikan tempat curahan hatinya. Informan KI menceritakan tentang permasalahan yang dialaminya hanya dengan sang kakak kandung.

Hal ini disebabkan oleh karakteristik tertentu yang membedakan antara pria dan wanita. Menurut Cohn, Strassberg \& Corby (dalam Mandasari, 2007), wanita biasanya mempunyai ciri khas seperti cenderung membuka diri, termasuk hal-hal yang bersifat pribadi, lebih berorientasi pada perasaan, senang terlibat dalam diskusi-diskusi intim, dan lebih terbuka dalam membicarakan perasaan mereka kepada orang lain. Dalam kehidupannya khususnya pergaulan, wanita 
cenderung memiliki banyak teman, senang memperkaya persahabatan untuk berbagi cerita, mencurahkan segala masalah yang dialaminya, serta memecahkan masalah merekasecara bersama-sama.

Sedangkan pria menurut Peetronio \& Weiss (dalam Mandasari, 2007), pada umumnya tidak suka membuka diri, terutama dalam hal yang berkaitan dengan hal-hal yang bersifat pibadi, karena bagi pria membuka diri berarti mengungkapkan kelemahan dan menurunkan sifat maskulinitasnya.Menurut Stein (dalam Mandasari, 2007) mengatakan bahwa dalam pergaulannya sehari-hari pria umumnya kurang mampu untuk beradaptasi dan hanya memiliki sedikit teman, selain itu pria hanya mempunyai sedikit pengalaman interpersonalnya.

Sadler (dalam Oktaria, 2009) mengatakan bahwa kesepian psikologikal datang dari kedalaman hati individu, baik itu yang berasal dari situasi masa kini ataupun sebagai reaksi dari trauma-trauma masa lalu.

Berdasarkan pernyataan Sadler (dalam Oktaria, 2009) diatas sesuai dengan hasil penemuan yang ditemukan pada informan $\mathrm{EH}$ yang mengalami kesepian psikologikal.Informan EH mengatakan bahwa pengalaman masa lalu membawa pengaruh dikehidupan saat ini.Sehingga membuat informan memilki perasaan kecewa, menyesal dan merasa bersalah karena merasa kena kualat. Menurut informan $\mathrm{EH}$, penyebab timbulnya perasaan demikian adalah karena dahulu sebelum informan EH pergi ke Ambon, informan EH pernah menjanjikan akan menikahi pacarnya, namun tidak jadi lantaran informan merasa hubungan dengan jarak jauh tidak akan berjalan lancar. Sehingga informan EH memutuskan untuk mengakhiri hubungannya. Informan EH mengatakan bahwa dirinya sudah berusaha untuk menghilangkan perasaan tersebut, namun terkadang disaat malam hari teringat akan kenangan sedih dimasa lalu.

Informan DI dan informan KI mengatakan hal yang sama bahwa kedua informan ini merasa pengalaman dimasa lalu tidak mempengaruhi kehidupan saat ini. Selain itu, kedua informan ini merasa bahagia meski belum memiliki pasangan hidup hingga saat ini.Berdasarkan pernyataan ini, ditemukan bahwa informan DI dan informan KI sama-sama tidak mengalami kesepian psikologikal seperti yang dikatakan oleh Sadler (dalam Oktaria, 2009).

Berdasarkan penelitian yang telah dilakukan, ditemukan bahwa informan EH mengatakan saat melakukan kegiatan diluar rumah dan aktivitas lain dilakukan sendiri. Informan EH juga mengatakan bahwa bisa melakukan aktivitasnya sendiri meski ada orang yang menawarkan bantuan.Hal ini senada dengan yang diungkapkan oleh informan DI yang mengatakan bahwa setiap melakukan aktivitas yang berkaitan diluar rumah, informan DI mengerjakan seorang diri.

Bruno (2000) mengatakan bahwa kesepian perilaku terjadi bila individu kurang atau tidak mempunyai teman sewaktu berjalan atau melakukan kegiatan diluar rumah, misalnya individu yang ingin menonton film atau ingin makan direstoran, namun tidak memiliki seorang teman yang dikenal yang bisa diajak. 
Dari pernyataan Bruno (2000), informan EH dan informan DI mengalami kesepian perilaku.Karena meskipun kedua informan ini mengatakan memiliki banyak teman, namun saat informan EH dan informan DI melakukan kegiatan diluar seperti jalan-jalan, makan diluar atau melakukan aktivitas yang lain dilakukan sendiri tanpa mengajak orang atau teman yang dikenal.

Berbeda dengan informan KI yang bisa dikatakan tidak mengalami kesepian perilaku seperti yang dikatakan oleh Bruno (2000).Karena informan KI saat melakukan aktivitas diluar seperti jalan-jalan atau makan diluar, informan KI masih bisa mengajak teman untuk menemaninya atau diajak teman untuk melakukan aktivitas diluar rumah bersama.

Berdasarkan penelitian yang telah dilakukan, ditemukan bahwa informan EH mengatakan bahwa kondisi dilingkungan sekitar tempat tinggalnya kondusif.Informan EH merasa nyaman tinggal dilingkungan tempat tinggalnya. Hubungan informan EH dengan orang disekitar tempat tinggal baik, tidak ada masalah.Namun, informan EH tidak memiliki peran dalam kelompok masyarakat dengan alasan sibukberjualan diangkringan.

Pernyataan informan EH sama dengan yang disampaikan oleh informan DI yang mengatakan merasa baik, aman, tidak ada gangguan, nyaman serta bersyukur tinggal dilingkungan tempat tinggal. Karena merasa tidak kesepian meskipun rumah seperti negeri Cina, karena disebelah kanan dan kiri rumah terdapat tembok.Informan DI memiliki peran didalam komunitas sepeda ontel sebagai tokoh Soekarno dan orang-orang menyebut sebagai maskotnya Banyumas sedangkan dilingkungan tempat tinggal tidak memiliki peran sosial.

Sedangkan pernyataan dari informan KI mengatakan bahwa informantinggal dilingkungan yang jumlah kepala keluarga sedikit dan jarang berinteraksi sosial. Keadaan dilingkungan tempat tinggal sepi, karena orang-orang disekitar sibuk bekerja.Meskipun demikianinforman tetap merasa nyaman tinggal dilingkungan tempat tinggalnya dan hubungan dengan tetangga baik.Informan mengatakan bahwa dirinya tidak memiliki peran sosial yang ada dilingkungan tempat tinggal karena tidak ada kegiatan seperti arisan atau kumpul RT.

Berdasarkan dari ketiga pernyataan informan yang telah dipaparkan diatas, informan yang menunjukkan mengalami kesepian sosial adalah informan $\mathrm{EH}$ dan informan KI.Karena meskipun kedua informan ini mengatakan merasa nyaman tinggal dilingkungan tempat tinggal dan merasa nyaman dan baik, namun kedua informan ini tidak memiliki peran sosial yang ada dimasyarakat sehingga jarang berinteraksi sosial.Hasil penemuan diatas sesuai dengan pendapat Robert Weiss (dalam Sears, Jonathan \& Peplau, 1988) yang mengatakan bahwa kesepian sosial terjadi bila orang kehilangan rasa terintegrasi secara sosial atau terintegrasi dalam suatu komunikasi, yang bisa diberikan oleh sekumpulan teman atau rekan sekerja.Berbeda dengan informan DI yang tidak menunjukkan kesepian sosial. Karena meskipun informan EH dan informan DI tinggal satu rumah, dan kondisi rumah kedua informan ini dikelilingi tembok besar, informan DI bahkan 
mengatakan seperti negeri Cina, namun dalam hal ini informan DI mengatakan tidak kesepian karena informan memiliki peran dikomunitas sepeda ontel yang menjadikan informan DI sering berinteraksi dengan orang lain.

Sadler (dalam Oktaria, 2009), culture shock terjadi ketika individu pindah ke suatu lingkungan kebudayaan baru. Berdasarkan pernyataan diatas, ditemukan bahwa ketiga informan yaitu informan $\mathrm{EH}$, informan DI dan informan KI mengatakan hal yang sama bahwa tidak pernah pindah rumah. Hanya saja informan EH pernah ke Ambon untuk bekerja dan tidak menetap lama.Informan EH mengatakan jika bertemu dengan lingkungan yang baru, informan EH mudah untuk menyesuaikan diri dan tidak ada masalah jika harus bertemu dengan lingkungan baru.Hal serupa juga disampaikan oleh informan DI yang merasa tidak kesulitan jika harus menyesuaikan diri dengan lingkungan yang baru dengan alasan memiliki banyak teman.Dengan demikian kedua informan ini, tidak mengalami culture shock seperti yang disampaikan oleh Sadler (dalam Oktaria, 2009).

Informan KI mengatakan tidak pernah pindah rumah dan hal ini yang kemungkinan menyebabkan informan merasa kesulitan untuk menyesuaikan diri jika harus berada dilingkungan baru.Pernyataan informan KI ini, menunjukkan bahwa informan mengalami culture shock yang terjadi ketika individu pindah ke suatu lingkungan kebudayaan baru seperti yang disampaikan oleh Sadler (dalam Oktaria, 2009).

\section{KESIMPULAN}

Penelitian ini dilakukan pada 3 orang tahap perkembangan middle age (masa dewasa pertengahan) yang masih melajang atau belum pernah menikah atau belum memiliki pasangan hidupyang ada di Purwokerto. Tujuan penelitian dilakukan adalah untuk mengkaji tipe-tipe kesepian.Informan yang menjadi informan penelitian yaitu EH dan DI berjenis kelamin pria dan KI berjenis kelamin wanita. Ketiga informan penelitian memiliki alasan yang berbeda tentang sebab atau alasan untuk tetap melajang sampai saat ini. Dari hasil penelitian ini ditemukan bahwa ketiga informan dengan jenis kelamin 2 pria dan 1 wanita, masing-masing informan memiliki beberapa tipe kesepian yang berbeda.Selain itu, ditemukan tipe kesepian yang sama yang dialami oleh ketiga informan penelitian yaitu tipe kesepian emosional dan tipe kesepian kognitif. Hal ini berarti menunjukkan bahwa ketiga informan memiliki masalah yang sama yaitu bersumber pada tipe kesepian emosional dan kognitif. Ketiga informan membutuhkan kasih sayang tetapi tidak mendapatkannya karena tidak ada figur kasih sayang yang intim dari lawan jenis atau dari keluarga serta hanya memiliki sedikit teman untuk berbagi pikiran atau mencurahkan segala perasaan yang terpendam. 


\section{DAFTAR PUSTAKA}

Bruno, F.J.S. (2000). Conguer Loneliness: Cara Menaklukan Kesepian. (Alih Bahasa: Sitanggang). Jakarta: PT. Gramedia Pustaka Utama.

Desmita. (2009). Psikologi Perkembangan. Bandung : PT. Remaja Rosdakarya.

Hurlock, E.B. (1980), Psikologi Perkembangan, Suatu Pendekatan Sepanjang Rentang Kehidupan, Edisi Kelima. (Alih Bahasa: Istiwidayanti \& Soedjarwo). Jakarta: Erlangga.

Mandasari, S.P. (2007). Perbedaan Loneliness pada Pria dan Wanita Usia Lanjut Setelah Mengalami Kematian Pasangan Hidup. Artikel Ilmiah dalam http://www.gunadarma.ac.id/library/articles/graduate/psychology/2007/Art ikel_10502248.pdf . Diakses pada 23 Oktober 2013.

Oktaria, R. (2009). Kesepian pada Pria Usia Lanjut yang Melajang. Artikel ilmiah dalam

http://www.gunadarma.ac.id/library/articles/graduate/psychology/2009/Art ikel_10504146.pdf Diakses pada 27 November 2013.

Papalia, D.E., Shally \& Ruth, (2008). Human Development: Psikologi Perkembangan Edisi Kesembilan. (Alih Bahasa: A.K. Anwar). Jakarta : Kencana.

Santrock, J.W. (1995). Life-Spain Development: Perkembangan Masa Hidup Edisi 5 Jilid II. (Alih Bahasa: Achmad Chusairi \& Juda Damanik). Jakarta: Erlangga.

Sears, D O, Jonathan,F L, \& Peplau,A, (1988). Social Psychology Fifth Edition. (Alih Bahasa: Michael Adryanto \& Savitri Soekrisno). Jakarta: Erlangga.

Suardiman, S.P. (2011). Psikologi Usia Lanjut. Yogyakarta: Gadjah Mada University Press.

Sumanto. (2014). Psikologi Perkembangan, Fungsi dan Teori. Yogyakarta: CAPS.

Wade, C \& Tavris. C, (2008). Psychology $9^{\text {th }}$ : Psikologi Edisi ke-9 Jilid 2. (Alih Bahasa: Padang Mursalin \& Dinastuti). Jakarta: Erlangga 